\title{
Quimioprofilaxis en coqueluche
}

\author{
WALTER LEDERMANN D.
}

\section{Pertussis chemoprophylaxis}

Palabras claves: Coqueluche; Quimioprofilaxis; Macrólidos.

Key words: Pertussis; Chemoprophylaxis; Macrolides.

La aplicación masiva de nuevas técnicas diagnósticas, que vienen a complementar el engorroso cultivo de Bordetella pertussis, como la IFD y la RPC, ha puesto en evidencia la participación de esta bacteria en la portación y en enfermedades subclínicas o atípicas, lo cual hace necesario distinguir dos entidades diferentes, cada una con su propia epidemiología: la coqueluche y el bacilo de Bordet y Gengou.

La coqueluche es una enfermedad clásica, con una sintomatología bien definida. En la definición de nuestro Ministerio de Salud (MINSAL), contenida en la Circular $\mathrm{N}^{\circ}$ 4/F de 1996, es un "cuadro caracterizado por tos de más de siete días, acompañada de paroxismos de tos, estridor inspiratorio, o vómito inducido por la tos", en tanto que para neonatos y lactantes bajo tres meses de edad, la tos con estridor se reemplaza por apneas repetidas.

Bordetella pertussis, por su parte, es una bacteria muy especial, capaz de producir, aparte de la coqueluche, portación asintomática y bordetelosis, como se ha llamado a aquellas formas de curso atípico, propias de quienes tienen pérdida parcial de la inmunidad que habían adquirido por vacunación o por enfermedad anterior, y que suelen verse en adolescentes y adultos. Así, para abordar el tema de la profilaxis, debemos ocuparnos primero de la Bordetella y luego de estas tres instancias en que podemos encontrarla.

Bordetella pertussis es un bacteria pequeñita, descrita como cocobacilo, pues nace cocácea y muere filamentosa, forma que va adquiriendo a través de sucesivos traspasos en medios artificiales. Taxonómicamente, pasó del género Haemophilus original al propio de Bordetella, ubica- do en la misma superfamilia que Acinetobacter, de quien viene siendo pariente muy cercana. Posee múltiples antígenos, que se han aplicado al desarrollo de vacunas, al igual que varias toxinas patogénicas, pero aquí nos interesa más su problemático cultivo, que dificulta su diagnóstico y la ubica entre las bacterias llamadas "fastidiosas".

Aparte de que no siempre puede obtenerse una buena muestra en niños, el cultivo es lento y engorroso. Los medios deben ser selectivos, para inhibir el desarrollo de la flora buco-faríngea; si resultan poco inhibidores, la Bordetella desaparece entre otras especies de cultivo más rápido; si se aumenta la concentración de antibiótico, suele inhibirse también ella misma. Como crece en dos a tres días, suele abrirse la placa un par de veces, para observar un posible desarrollo, favoreciendo el crecimiento de hongos ambientales. Por último, se da la paradoja que, siendo tan raro cultivarla con éxito, muchos bacteriólogos pocas veces han visto una y tienen dificultades para reconocer su colonia perlada entre la abundante flora circundante.

Para paliar estas dificultades, han surgido la IFD y la RPC. La primera es un examen de screening, bastante subjetivo, que debe confirmarse con el cultivo o con la clínica. La Academia Americana de Pediatría (AAP) la define como "de baja sensibilidad, variable especificidad, requiriendo interpretación por personal experimentado y, en suma, no confiable para confirmación diagnóstica en laboratorio". En cuanto a la RPC, pudiera reemplazar al cultivo, pero precisa laboratorios acreditados para su realización, ya que puede arrojar falsos positivos por contaminación 
o falsos negativos por impericia; en todo caso, ha permitido descubrir los portadores. Entonces... ¿qué hacemos? Un diagnóstico con base fundamentalmente clínica.

Siguiendo con la patología causada por Bordetella pertussis, tenemos la bordetelosis, en adultos y niños mayores que han perdido parcialmente la inmunidad. Consiste en un catarro, sin manifestaciones sistémicas, con una tos prolongada en el tiempo. Quienes sufren de este mal son responsables de hasta el $25 \%$ de los contagios en el hogar. Hodder et al detectaron esta patología en mayores de 65 años, en un trabajo clásico que demostró un alza significativa en anticuerpos anti- pertactina y anti- fimbria 2 .

Recapacitando, tenemos la bacteria causando coqueluche, bordetelosis y portación sana. Debemos hacer profilaxis a los contactos de los enfermos (coqueluche y bordetelosis), evaluar los contactos de los portadores y no considerar los contactos de las inmunofluorescencias.

Antes de entrar en la profilaxis, definamos qué es un contacto. Hace más de sesenta años, Miller y Faba estudiaron el problema, definiendo como exposición al contagio "jugar con un niño enfermo por lo menos un hora dentro de casa o dos horas al aire libre, en las primeras tres semanas de enfermedad, o bien, encontrarse frente a frente con un enfermo durante un acceso y a menos de $60 \mathrm{~cm}$ de distancia". En suma, una cercanía estrecha y por un buen rato, y no el caso del lactante que cruzó por el pasillo o estuvo un momento en la sala de espera sin toser.

La AAP recomienda la profilaxis en el hogar y otros close contacts, pero no en los colegios, sin importar edad ni estado vaccinal, monitorizando luego los síntomas respiratorios durante catorce días Nosostros, en el Calvo Mackenna, limitamos las indicaciones a tres instancias:

- Niños en riesgo de hacer enfermedad severa, como son los lactantes menores de 6 meses

- O en riesgo de hacer enfermedad mal tolerada, por patología basal, como ocurre en pacientes cardiopulmonares crónicos, mujeres embarazadas y senescentes.

- Y cuando claramente haya existido un contacto estrecho y largo con el enfermo.

La quimioprofilaxis tropieza con algunas dificultades al momento de elegir las herramientas, pues no hay estudios recientes de susceptibilidad in vitro en nuestro medio. Por sus antecedentes, elegimos macrólidos, de los cuales eritromicina está suficientemente validada, dejando los nuevos macrólidos como alternativas en mayores de 6 meses de edad. Mientras la AAP recomienda estolato de eritromicina $40 \mathrm{mg} / \mathrm{kg} /$ día, fraccionados cada 6 horas, por catorce días, nos parece más práctico e igualmente suficiente el esquema más corto del MINSAL, de sólo siete días, basándonos en ensayos terapéuticos que muestran similares resultados con una o dos semanas de antibiótico. Claritromicina también se usa por siete días y azitromicina por cinco.

Como otras alternativas pudieran emplearse dos recomendaciones antiguas, que luego fueron superadas por eritromicina: ampicilina y cloranfenicol, con la salvedad que su sensibilidad actual puede haber variado. También se recomienda cotrimoxazol, y no así las cefalosporinas, que han mostrado inesperada debilidad frente a Bordetella.

¿Y si vuelve a ser contacto? Si los contactos son repetidos, existe una falla médica o en el hogar, que no ha permitido prevenir esta sobreexposición. Si esta situación va a ser reiterada, es preferible revacunar antes que estar administrando tandas sucesivas de eritromicina.

Casos conflictivos sobre los que frecuentemente se consulta son:

- Colegios. No resulta práctico, porque durante un brote se van repitiendo las exposiciones y tendrían que irse repitiendo a la par las profilaxis masivas. Tampoco es fácil delimitar los verdaderos contactos, de manera que es preciso aplicar la norma general y considerar sólo las situaciones especiales de aquellos amigos más cercanos, con quienes juega de preferencia el "caso índice" y que son reales contactos, cuando tengan alguna patología de base que anticipe una coqueluche riesgosa, como se ha expresado anteriormente.

- Intrahospitalaria. En la misma sala, considerar el tiempo de exposición, las posibilidades reales de transmisión por expectoración, el comportamiento del personal a cargo y la patología de base que presentan los contactos, antes de decidir dispendiosas profilaxis masivas y repetidas.

- Personal a cargo de los enfermos. Si trabaja adecuadamente y cumple las normas mínimas de atención, no requiere profilaxis.

- Mujeres embarazadas. Está indicada.

- Contactos de los portadores. Si no están enfermos y no tosen, el riesgo de que contagien es escaso. Evaluar la situación con criterio conservador, aplicar las normas de aislamiento vigentes y no exagerar tratando los contactos de los contactos.

- IFD positivas. No homologarlas a portación si no hay sintomatología ni antecedentes epidemiológicos que la expliquen. 
Como conclusiones, hay que afinar el diagnóstico, no abusar de la IFD (no es fácil de leer ni barata); no tratar ni hacer profilaxis en casos de IFD positiva sin un cuidadoso análisis; hacer quimioprofilaxis a los contactos reales de los enfermos, siempre que se encuentren en condiciones especiales de riesgo; $\mathrm{y}$, por último, ante brotes el MINSAL debe aplicar las normas y definir las estrategias.

La coqueluche es una enfermedad misteriosa: no la hagamos, también, complicada.

\section{Bibliografía}

1.- American Academy of Pediatrics. Pertussis. En: Pickering LK. 2003. Red Book: Report of the Committee on Infectious Diseases. $26^{\text {th }}$ ed. Elk Grove Village, I L; American Academy of Pediatrics 2003.

2.- Cofré J. Coqueluche. En: Enfermedades Infecciosas en Pediatría. 3a edición. Mediterráneo, Santiago 2004: 392-6.

3.- Cofré J. Bordetella pertussis: fastidio para clínicos y epidemiólogos. Rev Chil Infectol 1999; 16 (1): 7-16.

4.- Hodder S L, Cherry J D, Mortimer Jr E A, Ford A B, Gornbein J, Papp K. Antibody responses to Bordetella pertussis antigens and clinical correlations in elderly community residents. Clin Infect Dis 2000; 31: 7-14.

Correspondencia a:

Walter Ledermann Dehnhardt

nmayor11@hotmail.com 